\title{
HUBUNGAN ANTARA KECERDASAN EMOSIONAL DAN KECERDASAN SPIRITUAL DENGAN PRESTASI BELAJAR PENDIDIKAN JASMANI
}

\author{
Rudy Saputra ${ }^{1}$, Amalia Barikah ${ }^{2}$ \\ STKIP Rosalia Lampung ${ }^{1}$ \\ Universitas Islam Kalimantan Muhammad Arsyad Al Banjari Banjarmasin ${ }^{2}$ \\ rudy.s23@yahoo.com \\ amaliabarikah29@gmail.com
}

\begin{abstract}
ABSTRAK
Tujuan penelitian ini untuk mengetahui hubungan antara kecerdasan emosional dengan prestasi belajar Pendidikan Jasmani, hubungan kecerdasan spiritual dengan prestasi belajar pelajaran Pendidikan Jasmani dan hubungan antara kecerdasan emosional dengan kecerdasan spiritual pada siswa - siswi kelas X di SMA Negeri 5 Metro. Sampel penelitian sebanyak 60 orang. Penelitian ini dapat disimpulkan bahwa hasil koefisien korelasi antara kecerdasan emosional dengan prestasi belajar pendidikan jasmani sebesar 0,84 dan hasil koefisien korelasi antara kecerdasan spiritual dengan prestasi belajar pendidikan jasmani sebesar 0,88 serta hasil koefiensi korelasi antara kecerdasan emosional dengan kecerdasan spiritual sebesar 0,80, dapat disimpulkan bahwa hubungan $\mathrm{X}_{1}$ dan $\mathrm{X}_{2}$ dengan variabel $\mathrm{Y}$ signifikan. Dengan demikian, semakin tinggi kecerdasan emosional dan kecerdasan spiritualnya semakin tinggi pula pestasi belajar Pendidikan Jasmaninya.
\end{abstract}

Kata Kunci : kecerdasan emosional, kecerdasan spiritual, prestasi belajar.

\section{RELATIONSHIP BETWEEN THE EMOTIONS INTELLIGENCE AND SPIRITUAL INTELLIGENCE WITH PHYSICAL EDUCATION LEARNING ACHIEVEMENT}

\begin{abstract}
The purpose of this research is to know a significant relationship between the emotions intelligence with physical education learning achievement, relationship between the spiritual intelligence with physical education learning achievement and relationship between the emotions intelligence with spiritual intelligence in students of class X SMA Negeri 5 Metro. Sample 60 students. The results showed that the emotional intelligence of the physical education learning achievement have a correlation coefficient 0,88 , the spiritual intelligence has a correlation coefficient 0,84 and the emotional intelligence of the spiritual intelligence has a correlation coefficient 0,80, so we can get the conclusion that corelation of $X_{1}$ and $X_{2}$ with variable $Y$ is significant. So that, the higher emotional intelligence and spiritual intelligence, of the higher achievement in Physical Education.
\end{abstract}

Keywords: emotions intelligence, spiritual intelligence, learning achievement

Dipublikasikan Oleh :

UPT Publikasi dan Pengelolaan Jurnal

Universitas Islam Kalimantan Muhammad Arsyad Al-Banjari Banjarmasin 


\section{PENDAHULUAN}

Sebuah pendidikan pada hakikatnya mempunyai tujuan untuk membangun manusia seutuhnya seperti yang tertera pada GBHN bahwa tujuan pendidikan adalah membentuk manusia yang utuh, maksudnya meliputi berbagai aspek tidak hanya aspek intelektual saja, tetapi juga aspek emosi dan spiritual. Namun kenyataannya pada saat ini pendidikan lebih mengutamakan aspek intelektual saja sebagai tolok ukur keberhasilan sebuah pendidikan (Syaparuddin and Elihami 2017)

Proses belajar di sekolah adalah proses yang sifatnya kompleks dan menyeluruh, banyak orang yang berpendapat bahwa untuk meraih prestasi yang tinggi dalam belajar, seseorang harus memiliki Intelligence Quotient (IQ) yang tinggi, karena inteligensi merupakan bekal potensial yang akan memudahkan dalam belajar dan pada gilirannya akan menghasilkan prestasi belajar yang optimal.

Penilaian terhadap hasil belajar seorang siswa untuk mengetahui sejauh mana telah mencapai sasaran belajar inilah yang disebut sebagai prestasi belajar.

Kenyataannya, dalam proses belajar mengajar Pendidikan Jasmani di sekolah sering ditemukan siswa yang tidak dapat meraih prestasi belajar yang setara dengan kemampuan inteligensinya. Ada siswa yang mempunyai kemampuan inteligensi tinggi tetapi memperoleh prestasi belajar Pendidikan Jasmani yang relatif rendah, namun ada siswa yang walaupun kemampuan inteligensinya relatif rendah, dapat meraih prestasi belajar Pendidikan Jasmani yang relatif tinggi, itu sebabnya taraf inteligensi bukan merupakan satu-satunya faktor yang menentukan keberhasilan seseorang, karena ada faktor lain yang mempengaruhi diantaranya adalah kecerdasan emosional atau Emotional Quotient (EQ) dan kecerdasan spiritual atau Spiritual Quotient (SQ).

Dalam proses belajar Pendidikan Jasmani, ketiga inteligensi itu sangat diperlukan.IQ tidak dapat berfungsi dengan baik tanpa partisipasi penghayatan emosional terhadap mata pelajaran yang disampaikan di sekolah dan kecerdasan spiritual berfungsi untuk mengendalikan kedua kecerdasan tersebut, biasanya ketiga inteligensi itu saling melengkapi. Keseimbangan antara IQ, EQ dan SQ merupakan kunci keberhasilan belajar siswa di sekolah. Pendidikan Jasmani di sekolah bukan hanya perlu mengembangkan rational intelligence yaitu model pemahaman yang lazimnya dipahami siswa saja, melainkan juga perlu mengembangkan emotional question serta spiritual question siswa .

Hal ini bertolak belakang dengan sistem pendidikan kita selama ini, yang terlalu menekankan pentingnya nilai akademik, kecerdasan otak (IQ) saja. Mulai dari tingkat dasar sampai bangku kuliah, jarang sekali dijumpai pendidikan tentang kecerdasan emosional sebagai kecerdasan untuk belajar mengakui dan menghargai perasaan diri sendiri dan orang lain untuk menanggapinya dengan tepat, menerapkannya dengan efektif energi emosi dalam kehidupan dan pekerjaan sehari - hari dan kecerdasan spiritual sebagai kecerdasan untuk menghadapi persoalan makna yaitu kecerdasan untuk menempatkan prilaku dan hidup kita dalam konteks makna yang lebih luas.

Masyarakat umum berasumsi bahwa seseorang dengan IQ tinggi dapat meraih prestasi yang tinggi juga, karena intelegensi akan memudahkan siswa dalam proses belajar mengajar, dengan itu juga akan menunjukkan hasil belajar yang baik. Namun, realitanya kebanyakan dari siswa yang mempunyai prestasi belajar tetapi tidak sebanding dengan taraf intelegensinya. Siswa dengan taraf intelegensi tinggi mempunyai prestasi belajar yang rendah, begitu sebaliknya. Siswa mampu meraih prestasi belajar yang tinggi walaupun intelegensinya rendah. Sehingga menurut Gusniwati (2015) faktor yang mempengaruhi keberhasilan belajar atau prestasi seseorang bukan hanya dari taraf intelegensinya saja, namun terdapat faktor lain yang mempengaruhi (Lestari et al. 2021)

Banyak contoh disekitar kita membuktikan bahwa orang memiliki kecerdasan otak saja, memiliki nilai tinggi, belum tentu sukses berkiprah di dunia pekerjaan. Seringkali justru yang berpendidikan formal yang lebih rendah, banyak yang ternyata mampu lebih berhasil. Kebanyakan program pendidikan hanya berpusat pada kecerdasan akal (IQ), padahal diperlukan pula bagaimana mengembangkan kecerdasan emosi seperti: ketangguhan, inisiatif, optimisme, kemampuan beradaptasi. Saat ini begitu banyak orang berpendidikan yang nampak begitu menjanjikan, mengalami kemandekan dalam kariernya. Lebih buruk lagi, mereka tersingkir akibat rendahnya kecerdasan emosi. Mengungkapkan kecerdasan (intelligence) adalah kemampuan bertindak dengan menetapkan suatu tujuan, untuk berpikir secara rasional, dan untuk berhubung dengan lingkungan di sekitarnya secara memuaskan (Firdaus Daud 2012)

Penyebab rendahnya prestasi atau hasil belajar siswa SMA sekarang ini sudah barang tentu tidak terlepas dari faktor umum. Pertama, yaitu faktor dari dalam diri siswa itu sendiri yang lazim disebut sebagai faktor internal dengan aneka macam bentuk dan jenisnya. Faktor ini banyak didominasi oleh kondisi psikologis beserta segenap potensi siswa dalam bentuk kecerdasan, termasuk intelegensi atau kecerdasan intelektual yang meliputi berbagai kemampuan, seperti penalaran, kemampuan berpikir abstrak, dan kemampuan verbal. Demikian juga faktor-faktor psikologis lainnya seperti konsep diri dan motivasi berprestasi. Juga faktor

Dipublikasikan Oleh : 
kecerdasan emosional yang meliputi ketabahan, keterampilan bergaul, empati, kesabaran, kesungguhan, keuletan, ketangguhan.

Kecerdasan emosional bertumpu pada hubungan antara perasaan, watak, dan naluri moral yang mencakup pengendalian diri, semangat dan ketekunan, kemampuan menyesuaikan diri, kemampuan memecahkan masalah pribadi, mengendalikan amarah serta kemampuan untuk memotivasi diri sendiri. Terutama dalam proses pembelajaran. Dalam proses pembelajaran terjadi suatu perubahan kemampuan yang dimiliki oleh siswa dalam berbagai bidang, dan kemampuan itu diperoleh karena adanya usaha belajar. Anakanak yang menguasai emosinya menjadi lebih percaya diri, optimis, memiliki semangat dan cita-cita, memiliki kemampuan beradaptasi sekaligus mereka akan lebih baik prestasinya di sekolah yang mampu memahami, sekaligus menguasai permasalahan-permasalahan yang ada. Kedua, yaitu faktor yang bersumber dari luar individu siswa, atau sering dikenal sebagai faktor eksternal. Faktor ini pun beraneka ragam, misalnya faktor lingkungan, baik lingkungan keluarga, maupun lingkungan sekolah dan masyarakat. Dalam lingkungan sekolah, guru dengan berbagai kompetensinya dipandang sebagai salah satu subfaktor yang turut memberikan andil dan kontribusi besar terhadap kesuksesan siswa dalam dunia pendidikan (Firdaus Daud 2012)

Kegagalan pendidikan yang paling fatal adalah ketika produk didik tidak lagi memiliki kepekaan nurani yang berlandaskan moralitas. Padahal subtansi pendidikan adalah memanusiakan manusia, menempatkan kemanusiaan pada derajat tertinggi. Ketika tidak lagi peduli, bahkan secara tragis, berusaha menyingkirkan eksestensi kemanusiaan orang lain, maka produk pendidikan barada pada tingkatan terburuknya.

Kasus tawuran antar pelajar SMA di Bogor menewaskan satu orang hanya dikerenakan saling ejek (Antara.com). Adanya perkelahian antar siswa, merebaknya kasus tawuran antar pelajar, beredarnya VCD / Video porno di sekolah, dan kasus pelajar melakukan tindakan asusila. Hal tersebut merupakan beberapa contoh lemahnya kecerdasan emosional (EQ) dan kecerdasan spiritual (SQ) dalam pendidikan.

Istilah kecerdasan emosional dan kecerdasan spiritual dalam pendidikan, bagi sebagian orang mungkin dianggap sebagai jawaban atas kejanggalan tersebut. Walaupun EQ dan SQ merupakan hal yang relatif baru dibandingkan IQ, namun beberapa penelitian telah mengisyaratkan bahwa kecerdasan emosional dan kecerdasan spiritual tidak kalah penting dengan IQ (Marsini 2015).

Bungawati, Taiyeb dan Hartati (2018) menemukan bahwa sebagian besar siswa di SMA masih acuh dalamproses belajar yang dilalui, hanya berorientasi pada nilai akhir yang didapatkan. Hal ini diduga karena kurangnya kecerdasan spiritual yang dimiliki siswa yang menyebabkan kurangnya pemaknaan di setiap aktivitasnya termasuk kegiatan dalam proses belajar, serta kurangnya kecerdasan emosional menyebabkan siswa kurang memiliki motivasi belajar dan siswapun tidak mudah berkonsentasi dalam memahami mata pelajaran Pendidikan Jasmani yang membutuhkan penalaran dan logika yang lebih dibandingkan dengan mata pelajaran lain (Lestari et al. 2021)

Karena sifat-sifat di atas, bila seseorang memiliki IQ tinggi namun taraf kecerdasan emosional dan kecerdasan spiritualnya rendah maka cenderung akan terlihat sebagai orang yang keras kepala, sulit bergaul, tidak dapat dipercaya, mudah frustrasi, tidak mudah percaya kepada orang lain, tidak peka dengan kondisi lingkungan, tidak bersyukur, sombong dan cenderung putus asa bila mengalami stress. Kondisi sebaliknya, dialami oleh orang-orang yang memiliki taraf IQ rata-rata namun memiliki kecerdasan emosional dan kecerdasan spititual yang tinggi (Ary Ginanjar Agustian 2001)

Berdasarkan uraian di atas peneliti tertarik untuk melakukan penelitian mengenai. " Hubungan Antara Kecerdasan Emosional dan Kercerdasan Spiritual Dengan Prestasi Belajar Pendidikan Jasmani pada Kelas X Di SMA Negeri 5 Metro "

\section{METODE}

(Suharsimi Arikunto 2002) metode penelitian adalah cara yang digunakan oleh peneliti dalam mengumpulkan data penelitian. Jenis penelitian yang digunakan adalah penelitian survei dengan teknik tes. Penelitian ini dilaksanakan di SMA Negeri 5 Metro.

Pengumpulan data kecerdasan emosional (EQ) dan kecerdasan spiritual (SQ) siswa dilakukan dengan cara penyebaran angket.

Uji validitas dilakukan untuk mengetahui apakah suatu skala psikologi mampu menghasilkan data yang akurat, artinya apakah item-item yang dibuat telah benar-benar mengungkap faktor yang ingin diselidiki. Uji validitas skala kecerdasan emosional (EQ) dan kecerdasan spirirual (SQ) dihitung dengan menggunakan rumus Korelasi Product Moment dari Pearson. Reliabilitas pada skala kecerdasan emosional (EQ) dan kecerdasan spiritual (SQ) dihitung dengan menggunakan rumus Alpha Cronbach.

Prestasi belajar siswa diperoleh dari nilai mata pelajaran Pendidikan Jasmani yaitu nilai raport kelas X semester 1. Teknik analisis data yang digunakan untuk melihat hubungan antara kecerdasan emosional dengn prestasi belajar adalah dengan menggunakan korelasi product moment dari Karl Pearson.

Dipublikasikan Oleh : 
Penekanan penelitian ini pada dimensi EQ, dan SQ sebagai bagian dari aspek individual yang mempengaruhi sikap etis mahasiswa akuntansi didasarkan pada ungkapan bahwa IQ merupakan kemampuan untuk mengarahkan pikiran atau tindakan, bertindak dengan tujuan tertentu, berpikir rasional, menghadapi lingkungan dengan efektif, serta dalam mengorganisasi pola-pola tingkah laku seseorang sehingga dapat bertindak lebih efektif dan lebih tepat. EQ adalah kemampuan mengetahui perasaan sendiri dan perasaan orang lain, serta menggunakan perasaan tersebut menuntun pikiran dan perilaku seseorang (M. Ridwan Tikollah, Iwan Triyuwono, and H. Unti Ludigdo 2006)

\section{HASIL DAN PEMBAHASAN}

Kecerdasan merupakan kemampuan untuk mengetahui problem serta kondisi baru, kemampuan berpikir abstrak, kemampuan bekerja, kemampuan menguasai tingkah laku instinktif, serta kemampuan menerima hubungan yang kompleks termasuk apa yang disebut dengan inteligensi (Firdaus Daud 2012)

Kecerdasan adalah kemampuan untuk menetapkan dan mempertahankan suatu tujuan, untuk mengadakan penyesuaian dalam rangka mencapai tujuan itu dan untuk bersikap kritis terhadap diri sendiri. Kecerdasan merupakan bakat tunggal yang dipergunakan dalam situasi menyelesaikan masalah apa pun. Seseorang yang tidak bisa memecahkan masalah atau persoalan semudah-mudahnya juga memiliki inteligensi hanya tarafnya yang rendah. Oleh karena itu, kecerdasan pada hakikatnya merupakan suatu kemampuan dasar yang bersifat umum untuk memperoleh suatu kecakapan yang mengandung berbagai komponen (Firdaus Daud 2012)

Sudjana (2005) menyatakan bahwa faktor dengan kontribusi yang lebih besar pada suatu keberhasilan belajar adalah faktor internal daripada faktor eksternal. Oleh karena itu, salah satu faktor internal yang berpengaruh pada prestasi belajar Pendidikan Jasmani sehinga menjadi titik fokus dalam penelitian kali ini, yaitu faktor psikologis meliputi kecerdasan.

Faktor psikologis yang dimaksud meliputi intelegensi atau kecerdasan siswa, minat, bakat, dan motivasi. Sehingga salah satu faktor psikologis yang mendukung keberhasilan belajar siswa adalah kecerdasan. Kecerdassan terbagi menjadi tiga macan, yaitu Intelligence Quotient (IQ), Emotional Quotient (EQ) dan Spiritual Quotient (SQ) (Lestari et alp. 2021)

Penelitian ini mengungkapkan hubungan antara kecerdasan emosional dan kecerdasan spiritual dengan prestasi belajar pendidikan jasmani dengan terlebih dahulu mengemukakan tentang deskripsi data, analisis data dan pembahasan penelitian.

Tabel 1. Hasil Analisis Data

\begin{tabular}{|c|c|c|c|c|c|c|}
\hline No & Hubungan & rhitung & $\mathbf{r}^{2}$ & ro & $T_{\text {tabel }}$ & Kesimpulan \\
\hline 1 & $\mathrm{X}_{1}$ dengan $\mathrm{Y}$ & 0,84 & 0,7056 & 0,84 & 0,25 & $\begin{array}{l}\text { Nilai ro }>\text { tabel, } \\
\text { dapat diartikan } \\
\text { ada hubungan } \\
\text { kecerdasan emosional } \\
\text { dengan prestasi belajar } \\
\text { pendidikan jasmani. }\end{array}$ \\
\hline 2 & $\mathrm{X}_{2}$ dengan $\mathrm{Y}$ & 0,88 & 0,7744 & 0,88 & 0,25 & $\begin{array}{l}\text { Nilai ro }>\text { tabel, } \\
\text { dapat diartikan } \\
\text { ada hubungan } \\
\text { kecerdasan spiritual } \\
\text { dengan prestasi } \\
\text { belajar pendidikan } \\
\text { jasmani }\end{array}$ \\
\hline 3 & $\mathrm{X}_{1}$ dengan $\mathrm{X}_{2}$ & 0,80 & 0,64 & 0,80 & 0,25 & $\begin{array}{l}\text { Nilai ro }>\text { tabel, } \\
\text { dapat diartikan } \\
\text { ada hubungan } \\
\text { kecerdasan emosional } \\
\text { dengan kecerdasan } \\
\text { spiritual }\end{array}$ \\
\hline
\end{tabular}

Keterangan: nilai $\mathrm{r}_{0}>\mathrm{r}$ tabel, maka $\mathrm{H}_{0}$ ditolak dan $\mathrm{H}_{1}$ diterima, nilai $\mathrm{r}_{0}>\mathrm{r}$ tabel, maka $\mathrm{H}_{0}$ ditolak dan $\mathrm{H}_{2}$ diterima, nilai $\mathrm{r}_{0}>\mathrm{r}$ tabel, maka $\mathrm{H}_{0}$ ditolak dan $\mathrm{H}_{3}$ diterima.

Dipublikasikan Oleh : 
Berdasarkan hasil analisis menunjukkan ada hubungan yang signifikan antara kecerdasan emosional (EQ) dengan prestasi belajar pendidikan jasmani. Tingkat hubungan kecerdasan emosional (EQ) dengan prestasi belajar pendidikan jasmani dapat dilihat dari besarnya koefisien korelasi (r). Hasil perhitungan diperoleh koefisien korelasi 0,84 , jika dikonsultasikan dengan kriteria koefisien korelasi termasuk kategori tinggi $(0,80$ $1,00)$.

Kecerdasan emosional merupakan kemampuan merasakan, memahami, dan secara efektif menerapkan daya dan kepekaan emosi sebagai sumber energi, informasi, koneksi dan pengaruh yang manusiawi. Kecerdasan emosional (emotional intelligence) adalah kemampuan untuk mengenali perasaan kita sendiri dan perasaan orang lain, kemampuan memotivasi diri sendiri, dan kemampuan mengelola emosi dengan baik pada diri sendiri dalam hubungan dengan orang lain. Seperti kesadaran diri, pengaturan diri, motivasi, empati, keterampilan sosial (Firdaus Daud 2012)

Kecerdasan emosional erat hubungannya dengan perasaan manusia. Emosi menuntut kita menghadapi saat-saat kritis dan tugas-tugas yang terlampau riskan bila hanya diserahkan kepada otak. Perasaan bisa dipengaruhi oleh beberapa faktor diantaranya sugesti, kelelahan, perhatian, intelegensi sehingga ikut mewarnai emosi (Syaparuddin and Elihami 2017)

Kecerdasan emosi (EQ) memegang peranan penting dalam pencapaian keberhasilan di segala bidang termasuk pendidikan. Menurut Robert K Cooper PhD, “ Hati mengaktifkan nilai - nilai kita yang terdalam, mengubahnya dari sesuatu yang kita pikir menjadi sesuatu yang kita jalani. Hati mampu mengetahui hal hal mana yang tidak boleh, atau tidak dapat diketahui oleh pikiran kita. Hati adalah sumber keberanian dan semangat, integritas serta komitmen. Hati adalah sumber energi dan perasaan mendalam yang menuntut kita untuk melakukan pembelajaran, menciptakan kerja sama, memimpin serta melayani (Ary Ginanjar Agustian 2001).

Menurut makalah McCleland tahun 1973 yang berjudul "Testing for Cometence Rather than Intelligence" dijelaskan tentang : "Seperangkat khusus seperti empati, disiplin diri, dan inisiatif akan membedakan antara mereka yang sukses sebagai bintang atau berpresetasi dengan yang hanya sebatas bertahan dalam pekerjaannya (Ary Ginanjar Agustian 2001)

EQ sangat berperan penting dalam keberhasilan hidup. Jika seseorang membuat kesal orang lain dengan perilaku kasar, tidak tahu cara membawa dan memposisikan diri, atau ambruk hanya karena stres sedikit saja, maka orang lain tidak akan betah bersamanya walau setinggi apapun IQ-nya (Firdaus Daud 2012)

Hal tersebut juga telah terbukti secara ilmiah bahwa kecerdasan emosi (EQ) memegang peranan penting dalam pencapaian keberhasilan di segala bidang termasuk pendidikan. Menurut Robert K Cooper PhD, " Hati mengaktifkan nilai - nilai kita yang terdalam, mengubahnya dari sesuatu yang kita pikir menjadi sesuatu yang kita jalani. Hati mampu mengetahui hal - hal mana yang tidak boleh, atau tidak dapat diketahui oleh pikiran kita. Hati adalah sumber keberanian dan semangat, integritas serta komitmen. Hati adalah sumber energi dan perasaan mendalam yang menuntut kita untuk melakukan pembelajaran, menciptakan kerja sama, memimpin serta melayani (S. Bakhri 2015)

Kecerdasan emosional merupakan landasan bagi prestasi belajar siswa yang meliputi kemampuan mengendalian diri sendiri, memiliki semangat dan ketekunan, memotivasi diri sendiri, ketahanan menghadapi frustasi, kemampuan mengatur suasana hati, kemampuan empati. Orang yang dapat mengendalikan emosi secara cepat dan memperhatikan serta memikirkan perasaan orang lain dapat disebut sebagai orang yang cerdas emosional. Semakin tinggi kecerdasan emosional maka semakin tinggi dalam menentukan prestasi belajar siswa.

Berdasarkan hasil analisis menunjukkan ada hubungan yang signifikan antara kemampuan kecerdasan spiritual dengan prestasi belajar pendidikan jasmani. Tingkat hubungan kecerdasan spiritual (SQ) dengan prestasi belajar pendidikan jasmani dapat dilihat dari besarnya koefisien korelasi ( $r$ ). Hasil perhitungan diperoleh koefisien korelasi 0,88, jika dikonsultasikan dengan kriteria koefisien korelasi termasuk kategori kategori tinggi $(0,80$ - 1,00). (Suharsimi Arikunto 2010).

Menurut Danah Zohar dan Ian Marshall, orang yang pertama kali mengeluarkan ide tentang konsep kecerdasan spiritual, mendefinisikan kecerdasan spiritual adalah kecerdasan untuk menghadapi dan memecahkan persoalan makna dan nilai. Kecerdasan yang memberi makna, yang melakukan kontektualisasi, dan bersifat transformatif. Mereka mengatakan kecerdasan untuk menempatkan perilaku dan hidup kita dalam konteks makna yang lebih luas dan kaya. Dan kecerdasan itu untuk menilai bahwa tindakan atau jalan hidup seseorang lebih bermakna dibandingkan dengan yang lain (Syaparuddin and Elihami 2017)

Kecerdasan spiritual (SQ) adalah kecerdasan untuk menghadapi dan memecahkan persoalan makna dan nilai, yaitu menempatkan perilaku dan hidup manusia dalam konteks makna yang lebih luas dan kaya, serta

Dipublikasikan Oleh :

UPT Publikasi dan Pengelolaan Jurnal

Universitas Islam Kalimantan Muhammad Arsyad Al-Banjari Banjarmasin 
menilai bahwa tindakan atau jalan hidup seseorang lebih bermakna dibandingkan dengan yang lain (Zohar \& Marshall, 2002:4). SQ melampaui kekinian dan pengalaman manusia, serta merupakan bagian terdalam dan terpenting dari manusia (M. Ridwan Tikollah et al. 2006)

Kecerdasan spiritual (SQ) adalah landasan yang diperlukan untuk memfungsikan IQ, EQ secara efektif. Bahkan SQ merupakan kecerdasan tertinggi kita (Danah Zohar dan Ian Marshall, "SQ : Spiritual Intellegence", Bloomsbury, Great Britain). Dalam proses pembelajaran kita menggunakan SQ untuk mencapai perkembangan diri yang lebih utuh (Danah Zohar Ian Marshall 2001)

Kita masing - masing membentuk suatu karakter melalui gabungan antara pengalaman dan visi. Pada tingkatan ego murni kita adalah egois, ambisius terhadap materi, serba aku dan sebagainya

SQ memberikan gambaran - gambaran terhadap kebaikan, keindahan, kesempurnan, kedermawanan, dan pengorbanan. SQ juga membantu kita menjalani hidup pada tingkatan makna yang lebih dalam proses pembelajaran, sehingga lebih memotivasi kita untuk lebih berprestasi dari pada orang lain (Danah Zohar Ian Marshall 2001).

Kecerdasan spiritual (SQ) itu menurut penelitian-penelitian di bidang neurology, punya tempat yang khusus dalam otak. Ada bagian dari otak kita yang memiliki kemampuan untuk mengalami pengalamanpengalaman spiritual, misalnya untuk memahami Tuhan, memahami sifat- sifat Tuhan. Maksudnya adalah menyadari kehadiran Tuhan di sekitar kita dan untuk memberi makna dalam kehidupan. Orang yang cerdas secara spiritual diantaranya bisa dilihat ciri-cirinya antara lain yaitu, bisa memberi makna dalam kehidupannya, senang berbuat baik, senang menolong orang lain, telah menemukan tujuan hidupnya, dia merasa memikul misi yang mulia, dia merasa dilihat oleh Tuhannya (Syaparuddin and Elihami 2017)

Kecerdasan spiritual (SQ) adalah kunci untuk mencapai prestasi belajar Pendidikan Jasmani karena dengan memiliki kecerdasan spiritual (SQ) Anda akan menjadi manusia yang penuh belas kasih terhadap sesama, memiliki empati dan kepedulian terhadap orang lain, mendahulukan kepentingan orang lain diatas kepentingan pribadi, mampu menghargai dan menghormati orang lain dan menyikapi segala sesuatu dengan melihat dari sudut pandang yang lebih luas. Dengan memiliki kecerdasan spiritual (SQ) yang tinggi, Anda akan tumbuh menjadi orang yang selalu berpikir positif dalam menjalani proses pembelajaran. Anda, mampu bangkit dari setiap kegagalan, penderitaan dan cobaan dengan melihat makna yang terkandung didalamnya. Makna kehidupan yang bisa Anda dapatkan dengan memiliki kecerdasan spiritual (SQ) adalah terbebasnya rohani atau jiwa Anda dari hasrat duniawi seperti keserakahan, kesombongan, nafsu, rasa dendam, benci (Fazari, Muhamad, Imas Damayanti 2017)

Kecerdasan spiritual (SQ) adalah landasan yang diperlukan untuk memfungsikan IQ, EQ secara efektif. Bahkan SQ merupakan kecerdasan tertinggi kita (Danah Zohar Ian Marshall 2001)

Indikasi dari SQ yang telah berkembang dengan baik mencakup: a) Kemampuan untuk bersikap fleksibel, b) Adanya tingkat kesadaran diri yang tinggi, c) Kemampuan untuk menghadapi dan memanfaatkan penderitaan, d) Kemampuan untuk menghadapi dan melampaui perasaan sakit, e) Kualitas hidup yang diilhami oleh visi dan nilai-nilai, f) Keengganan untuk menyebabkan kerugian yang tidak perlu, g) Kecenderungan untuk berpandangan holistik, h) Kecenderungan untuk bertanya "mengapa" atau "bagaimana jika" dan berupaya untuk mencari jawaban-jawaban yang mendasar, i) Memiliki kemudahan untuk bekerja melawan konvensi (M. Ridwan Tikollah et al. 2006)

Berdasarkan hasil analisis menunjukkan ada hubungan yang signifikan antara kecerdasan emosional (EQ) dengan kecerdasan spiritual (SQ). Tingkat hubungan antara kecerdasan emosional (EQ) dengan kecerdasan spiritual (SQ) dapat dilihat dari besarnya koefisien korelasi (r). Hasil perhitungan diperoleh koefisien korelasi 0,80, jika dikonsultasikan dengan kriteria koefisien korelasi termasuk kategori tinggi $(0,80-1,00)$. (Suharsimi Arikunto 2010)

Kedua kecerdasan dasar kita tersebut bekerja sama dan saling mendukung. Otak kita dirancang untuk melakukakan hal itu. Meskipun demikian mereka (EQ dan SQ) masing - masing memiliki wilayah kekuatan tersendiri dan bisa berfungsi secara terpisah. SQ menjadikan kita makhluk yang benar - benar utuh secara intelektual, emosional dan spiritual (Danah Zohar Ian Marshall 2001).

Semua siswa - siswi pasti ingin meraih kesuksesan dalam pembelajaran. Namun tidak semua orang dapat mewujudkannya.Orang-orang yang sukses memiliki rahasia dalam meraih kesuksesannya.Rahasia kesuksesannya terletak pada kekuatan dan bakat dari batin dan jiwa mereka.Orang sukses memanfaatkan kekuatan dan bakat dari batin dan jiwa yang mereka miliki untuk mewujudkan kesuksesan dalam kehidupan mereka. Kecerdasan spiritual (SQ) juga berasal dan bersumber dari batin dan jiwa manusia. Dengan demikian orang yang memiliki kecerdasan spiritual (SQ) yang tinggi akan mudah meraih kesuksesan dalam hidupnya.

Spiritual Quotient (SQ) juga yang mendasari dalam menyambungkan antara Intelligance Quatient (IQ) dan Emotional Quotient (EQ) dengan berhasil. Sesuai dengan Zohar (Azzet, 2010) yang menyatakan bahwa

\author{
Dipublikasikan Oleh : \\ UPT Publikasi dan Pengelolaan Jurnal \\ Universitas Islam Kalimantan Muhammad Arsyad Al-Banjari Banjarmasin
}


kecerdasan spiritual adalah keceredasan tertinggi yang mengelaborasikan kecerdasan intelektul dan kecerdasan emosional, sebab sangat berkaitan dengan kesadaran seseorang agar dapat mengartikan sesuatu hingga merasakan sebuah kebahagiaan (Lestari et al. 2021)

SQ adalah landasan yang diperlukan untuk memfungsikan IQ dan EQ secara efektif, bahkan SQ merupakan kecerdasan tertinggi kita (Danah Zohar Ian Marshall 2001).

Kedua kecerdasan dasar kita tersebut bekerja sama dan saling mendukung. Otak kita dirancang untuk melakukakan hal itu. Meskipun demikian mereka (EQ dan SQ) masing - masing memiliki wilayah kekuatan tersendiri dan bisa berfungsi secara terpisah. SQ menjadikan kita makhluk yang benar - benar utuh secara intelektual, emosional dan spiritual. (Ary Ginanjar Agustian 2001)

Seseorang yang memiliki SQ tinggi akan mampu memperoleh jiwa dengan penuh pemaknaan, sehingga akan muncul ketenangan di dalam hatinya. Hati yang tenang akan memberikan tanda pada tubuh agar menurunkan kerja simpatis menjadi para simpatis, aliran darahpun akan mengalir dengan teratur sehingga dapat berpikir secara optimum. Jika siswa dapat berpikir secara optimum, maka siswa dengan mudah akan lebih mengerti. Lalu, hasil belajar Pendidikan Jasmani akan meningkat. Oleh sebab itu, EQ dan SQ ternyata memiliki hubungan kesatuan yang saling berkaitan. Dengan demikian, muncullah istilah Emotional Spiritual Quotient (ESQ). (Lestari et al. 2021)

ESQ (Emotional Spiritual Quotient) adalah suatu metode pembangunan jiwa yang mengelaborasikan dua jenis kecerdasan, yaitu Emotional Quotient (EQ) dan Spirital Quotient (SQ) yang menggunakan kekuatann pikiran bawaah sadar (suara hatii) atau God Spot. Selain itu, Agustian juga mendefinisikan Emotional Spritual Quotient (ESQ) sebagai berikut: Emotional Spiritual Quotient (ESQ) yaitu suatu kecerdasan yng mencakup emosi dan spiritual dengan rancangan yang menyeluruh hingga dapat menyalurkan dirinya pada kriteria kepuasan baik untuk dirinya sendiri maupun sekitar, serta dapat menurunkan hal-hal negatif dalam kebermanfaatan umat manusia (Lestari et al. 2021)

Dalam rangka mengaktualisasikan kecerdasan emosional (EQ) dan kecerdasan spiritual (SQ) sangat dipengaruhi oleh beberapa faktor yang sangat mendominasi, baik itu berasal dari sekolah, maupun luar sekolah dalam hal ini adalah lingkungan keluarga. Melalui pengamatan yang dilakukan peneliti, bisa diambil satu faktor yang sangat dominan dalam mengaktualisasikan dua kecerdasan tersebut (EQ dan SQ), yakni lingkungan. Dimana dia tinggal dan peraturan atau perhatian yang mereka dapat dari seorang teman, keluarga dan Guru (Fazari, Muhamad, Imas Damayanti 2017)

Kecerdasan spiritual ternyata memberikan pengaruh pada tingkah laku seseorang dalam berprestasi. Menurut penelitian Chakraborty dan Chakraborty (2004) menyatakan bahwa terdapat hubungan antara kecerdasan spiritual dan kepemimpinan. Spiritualitas berpengaruh terhadap bagaimana seseorang bersikap sebagai pemimpin. Pemimpin yang baik adalah mereka yang memiliki kecerdasan spiritual yang bagus, serta dapat membawa nilai-nilai spiritualitas dalam kepemimpinannya. Mereka yang berperilaku demikian akan lebih dihargai oleh para bawahannya, sehingga hasil kerja yang dihasilkan akan lebih baik karena setiap orang dapat belajar saling memahami dan menghargai. Hal tersebut juga sama terhadap penelitian dari Rezaei, Kazemi, dan Isfahani (2011) yang menyatakan bahwa terdapat pengaruh yang positif antara kecerdasan spiritual terhadap prestasi belajar. Sedangkan menurut penelitian Tischler, Biberman, dan Mckeage (2002), kecerdasan emosional dan kecerdasan spiritual mempunyai pengaruh positif tehadap kesuksesan pada individu(Wibowo 2017).

Dengan demikian, jika seseorang mempunyai tingkat ESQ yang tinggi, maka ia akan memiliki kemampuan untuk mengelola pribadinya secara mantap. Ia akan mampu mengendalikan diri, mempunyai dorongan untuk terus berprestasi, menjadi orang yang dapat dipercaya, optimis dalam segala urusan, dapat memahami orang lain disekitarnya, serta bertanggungjawab atas perbuatan yang telah ia lakukan baik terhadap Tuhan maupun terhadap manusia lain. Dengan demikian dengan tersirat akan memudahkan ia pada proses belajar mengajar, terkhusus pada matta pelajaran matematiika dan berimbas pada hasil belajar Pendidikan Jasmani siswa yang baik (Lestari et al. 2021)

Di dalam kurikulum 2013 yang diterapkan di sekolah ternyata juga mendukung adanya peningkatan ESQ. Karena di kurikulum 2013 terdapat empat aspek penilaian, yaitu aspek pengetahuan, keterampilan, sikap dan perilaku. Oleh karena itu, sekolah kini melaksanakan pembiasaan karakter guna mencapai salah tujuan pendidikan nasional, yaitu mengembangkan kemampuan dan membentuk watak serta peradaban bangsa yang bermartabat dalam rangka mencerdaskan kehidupan bangsa, bertujuan untuk mengembangkan potensi peserta didik agar menjadi manusia yang beriman dan bertakwa kepada Tuhan Yang Maha Esa, berakhlak mulia, sehat, berilmu, cakap, kreatif, mandiri, dan menjadi warga negara yang demokratis serta bertanggung jawab.(Lestari et al. 2021)

Menurut Agustian (2016) menyatakan bahwa kegiatan pembiasaan siswa di sekolah yang dilakukan berdasarkan rukun Islam seperti dan puasa merupakan hasil pembangunan karakter dalam rangka meningkatkan kecerdasan emosional dan spiritual secara berkala, serta suatu cara untuk mengasah dan mempertajam

Dipublikasikan Oleh :

UPT Publikasi dan Pengelolaan Jurnal

Universitas Islam Kalimantan Muhammad Arsyad Al-Banjari Banjarmasin 
kecerdasan emosional dan spiritual dari rukun iman. Selain itu, ibadah yang dilakukan seperti puasa juga sebagai metode pelatihan dalam mengendalikan diri dan suasana hati. Sehingga dapat dikatakan bahwa ESQ memiliki peran penting dalam pengendalian diri seseorang. Dengan demikian pula dapat dikatakan jika mempunyai ESQ yang tinggi, maka secara langsung akan mempunyai kesadaran juga agar dapat mengendalikan dan mengelola emosi yang tentu akan berdampak pada prilakunya, serta memiliki motivasi untuk berprestasi, optimis, dapat berkomunikasi dengan baik serta mampu bekerja sama. Hal ini sejalan dengan penelitian yang dilakukan oleh Nurdiansyah (2016), Herawati dan Mulyanratna (2014) menghasilkan bahwa terdapat hubungan antara kecerdasan emosional dan kecerdasan spiritual baik secara parsial maupun secara simultan (bersama-sama) dengan hasil belajar dengan kategori kuat (Lestari et al. 2021)

\section{PENUTUP}

Ada hubungan yang signifikan antara kecerdasan emosional (EQ) dengan prestasi belajar pendidikan jasmani, ada hubungan yang signifikan antara kecerdasan spiritual (SQ) dengan prestasi belajar pendidikan jasmani, ada hubungan yang signifikan antara kecerdasan emosional (EQ) dengan kecerdasan spiritual (SQ).

Berdasarkan hasil penelitian dan pembahasan di atas, maka dapat diajukan saran-saran sebagai berikut :Untuk mengembangkan dan mengoptimalkan kecerdasan emosional (EQ) dan kecerdasan spiritual (SQ) yang berperan dalam keberhasilan siswa baik di sekolah maupun di lingkungan sekitarnya, maka disarankan kepada pihak sekolah terutama guru-guru pengajar agar memasukkan unsur-unsur kecerdasan emosional (EQ) dan kecerdasan spiritual (SQ) dalam menyampaikan materi serta melibatkannya dalam proses pembelajaran.

Bagi para meneliti untuk penelitian selanjutnya sebaiknya di dalam pengambilan data tentang prestasi belajar tidak menggunakan nilai mata pelajaran Pendidikan Jasmani secara keseluruhan melainkan difokuskan pada salah satu materi yang ada didalam silabus sehingga hasil dari data tersebut sesuai dengan yang diharapkan.

\section{REFERENSI}

Ary Ginanjar Agustian. 2001. Rahasia Sukses Membangun Kecerdasan Emosi Dan Spiritual (ESQ). Jakarta: PT : Arga Wijaya Persada.

Danah Zohar Ian Marshall. 2001. SQ: Memanfaatkan Keserdasan Spiritual Dalam Berpikir Integralistik Dan Holistik Untuk Memaknai Kehidupan. Bandung: Mizan.

Fazari, Muhamad, Imas Damayanti, Nur Indri Rahayu. 2017. "Hubungan Kecerdasan Inteleqtual ( IQ ) Dan Keterampilan Bermain Dalam Cabang Olahraga Bulu Tangkis.” 02(01):33-37.

Firdaus Daud. 2012. "Pengaruh Kecerdasan Emosional (EQ) Dan Motivasi Belajar Terhadap Hasil Belajar Biologi Siswa SMA 3 Negeri Kota Palopo.” Jurnal Pendidikan Dan Pembelajaran Universitas Negeri Malang 19(2):243-55.

Lestari, Ayu, Cecep Anwar, Hadi Firdos, and Ria Sudiana. 2021. "Pengaruh Intellegence Quotient ( IQ ) Dan Emotional Spiritual Quotient ( ESQ ) Terhadap Hasil Belajar Matematika Siswa SMA ( Studi Korelasi Siswa SMA Se-Kota Serang ).” 4(3):497-506. doi: 10.22460/jpmi.v4i3.497-506.

M. Ridwan Tikollah, Iwan Triyuwono, and H. Unti Ludigdo. 2006. "Pengaruh Kecerdasan Intelektual, Kecerdasan Emosional Dan Kecerdasan Spiritual Terhadap Sikap Etis Mahasiswa Akuntansi (Studi Pada Perguruan Tinggi Negeri Di Kota Makassar Provinsi Sulawesi Selatan).” Simposium Nasional Akuntansi 9 Padang 1-25.

Marsini. 2015. "Kecerdasan Spiritual Dalam Menghindari Perilaku Menyimpang Pada Siswa." Jurnal Pendidikan Jasmani Unila 151(04):10-17. doi: 10.1145/3132847.3132886.

S. Bakhri. 2015. "Emotional Spiritual Quotient (ESQ) Menurut Ary Ginanjar Agustian Dan Relevansinya Dengan Pengembangan Kompetensi Spiritual Dan Kompetensi Sosial Kurikulum 2013." Skripsi 151(1):10-17.

Suharsimi Arikunto. 2002. Metode Penelitian Suatu Pendekatan Praktik. Jakarta: PT. Rineka Cipta.

Suharsimi Arikunto. 2010. Prosedur Penelitian Suatu Pendekatan Praktek. Jakarta: PT. Rineka Cipta.

Dipublikasikan Oleh :

UPT Publikasi dan Pengelolaan Jurnal

Universitas Islam Kalimantan Muhammad Arsyad Al-Banjari Banjarmasin 
Syaparuddin, Syaparuddin, and Elihami Elihami. 2017. "Peningkatan Kecerdasan Emosional (EQ) Dan Kecerdasan Spiritual (SQ) Siswa Sekolah Dasar SD Negeri 4 Bilokka Sebagai Upaya Meningkatkan Kualitas Diri Dalam Proses Pembelajaran PKN.”Jurnal Pendidikan Guru Sekolah Dasar 1(2):1-19.

Wibowo, Cahyo Tri. 2017. “Analisis Pengaruh Kecerdasan Emosional (Eq) Dan Kecerdasan Spiritual (Sq) Pada Kinerja Karyawan.” Jurnal Bisnis Dan Manajemen 15(1):1. doi: 10.20961/jbm.v15i1.4108. 